\title{
PARENTING STYLE IN FAMILY WITH ADOLESCENT CHILD: FAMILY ECOLOGY PERSPECTIVE
}

\author{
Gaya Pengasuhan pada Keluarga dengan Anak Remaja: Perspektif Ekologi \\ Keluarga \\ SINTA SUSANTO PUTRI ${ }^{1^{\star}}$, LIN SHU LING ${ }^{1}$ \\ ${ }^{1}$ Graduate Institute of Family Education and Counseling, \\ National Chiayi University, Taiwan
}

\begin{abstract}
ABSTRAK. Tujuan dari penelitian ini adalah untuk menguji pengaruh faktor ekologis terhadap gaya pengasuhan, dengan mempertimbangkan pengaruh status sosial ekonomi, etnis, dukungan sekolah, dan masyarakat/lingkungan dukungan orang tua dalam penerapan gaya pengasuhan. Penelitian ini merupakan penelitian cross sectional yang menggunakan metode survei sebagai desain penelitian dan menggunakan kuesioner sebagai alat pengumpulan data. Responden dalam penelitian ini adalah para ibu dari 400 orang siswa dari kelas 10 hingga kelas 12 di SMU Budhi Warman I, Jakarta Timur. Hasil penelitian menunjukkan bahwa nilai orang tua [subscale goal incentives from children] memiliki perbedaan yang nyata berdasarkan etnis yang dimiliki oleh ayah, etnis ibu [subscale continuity, tradition, and security], dan status sosial ekonomi [subscale happiness and affection]. Dalam hal gaya pengasuhan terdapat perbedaan yang nyata pada gaya pengasuhan berdasarkan etnis ayah (gaya pengasuhan permisif) dan status sosial ekonomi (gaya pengasuhan otoriter). Hubungan keluarga-sekolah dan hubungan keluarga-masyarakat memiliki korelasi positif dan signifikan dengan nilai orang tua dan dengan gaya pengasuhan. Sebaliknya, penelitian ini menemukan bahwa status sosial ekonomi dan etnis tidak memiliki hubungan yang signifikan dengan nilai orang tua dan gaya pengasuhan. Beberapa analisis regresi menunjukkan bahwa nilai orang tua merupakan moderator parsial yang signifikan untuk menengahi hubungan antara hubungan keluarga-sekolah dan keluarga-masyarakat berkaitan dengan gaya pengasuhan.
\end{abstract}

\section{Key words: adolescent, family-community connection, family-school} connection, family-parental value, parenting style.

\section{INTRODUCTION}

Family is the one and the important institution in human living. Families provide children with a sense of belonging and a unique identity. The family environment can be a strong source of support for developing children, providing close relationships, strong parenting skills, good communication, and modeling positive behaviors. It can also be a problematic environment when those supports are lacking, such as negative adult behaviors like smoking and heavy drinking are present.

Parents shape the lives of their children from birth through adulthood. In adolescence, the influence of friends and peers take on greater importance, but research clearly demonstrates the continued significance of parents in shaping the behaviors and choices of teens as they face the challenges of growing up (Matas, Arend, and Sroufe 1978, Abar, Carter and Winsler 2009, Brofenbrenner 1986). Close parentadolescent relationships, good parenting skills, shared family activities, and positive parent role modeling had been welldocumented that had effects on adolescent health and development. These are also areas where parents can make choices to make positive changes to their children, and where social policy can support parents in taking such steps. 
Thus, parenting is a complex process, involving much more than a mother or father providing food, safety, and support to an infant or child. Parenting involves bidirectional relationships between members of two (or more) generations; can extend through all or major parts of the respective life spans of these groups; may engage all institutions within a culture (including educational, economic, political, and social ones); and is embedded in the history of a people--as that history occurs within the natural and designed settings within which the group lives (Ford \& Lerner, 1992). Given, then, the temporal variation that constitutes history, the variation of culture and of its institutions that exist in different physical and designed ecological niches, and the variation, within and across generations, in strategies for and behaviors designed to fit with these niches, we may note that diversity is a key substantive feature of parenting behavior. Focus on this variation, rather than on central tendencies, is necessary in order to understand parenting adequately. In addition, there are multiple levels of organization that change in and through integrated, mutually interdependent or "fused" relationships; these relationships occur over both ontogenetic and historical time (Lerner \& Lerner 1987; Tobach \& Greenberg 1984). As such, context, as well as diversity, is an important feature of parenting.

Parenting is engage with family ecology. Families are interdependent on their neighborhood, social, and physical environment. Basically, the perspective explores the families' development being affected by the environment it resides in. The interaction a family has three major environments that has a large impact upon that institution. The neighborhood they reside in, their social environment, and their physical environment influence the family. Parenting strategies have been associated with complex interactions between biological, psychological, and socioenvironment factors.

Based on this background, this study examined the ecological aspect of parenting style strategies in family with adolescent children. This study attempted to clarify the relationships among ethnicity, socioeconomic status, community, and neighborhood support and children's own attributes, and how those factors interact to ultimately influence parenting style strategies.

The purposes of this research are to analyze the influences of ecological aspect of parenting style such as socioeconomic status, ethnicity neighborhood and community and school to parenting style strategies. Beside that this research also analyzes the difference between parental belief and value, and parenting style strategies.

\section{METHOD}

\section{Research Design}

This research used cross sectional study with questionnaire survey method as research design. Questionnaire Survey research is one of the most important areas of measurement in applied social research. It used paper-and-pencil instruments that the respondent completed.

\section{Participant and Sample}

Participants of this research are the mothers of student of Budhi Warman I High School, East Jakarta. The participants selected cluster randomly and four hundred participants selected for this research.

This research was conducted from February, $2^{\text {nd }}$ until $14^{\text {th }}, 2009$ with structure questionnaires. The questionnaires were distributed to samples of parents who have adolescent children in the Budhi Warman I High School. From 400 questionnaires, 133 gathered from level 10, 127 gathered from level 11 , and 140 gathered from level 12 . This study used clustering sampling based on level of students.

Sample characteristics including four major items, there are: (1) ethnicity, (2) education, (3) socioeconomic status, and (4) age.

The mothers ranged in age from 26 to 60 years old and there were $65.30 \%$ of the mother are $40-50$ years old $(M=43.87$; $S D=5.19)$. The ages of the fathers ranged from 30 to 61 years old and more than half $(61.80 \%)$ father are $40-50$ years old $(M=47.42 ; \quad S D=6.69)$. Moreover, $62 \%$ mothers had education level of senior high school $(M=3.87 ; S D=1.41)$ while $10.30 \%$ mothers were not graduated from elementary school and likewise $51.40 \%$ 
fathers had education level of senior high school, while $6.30 \%$ fathers were not graduated from elementary school $(\mathrm{M}=4.22 ; \quad S D=1.44)$. Both father and mother have highest percentage in Java ethnic (father=47\%; $M=2.48 ; \quad S D=2.04$ and mother 50\%; $M=2.21 ; \quad S D=1.60)$. Nearly half of families $(49.30 \%)$ had high level socioeconomic status.

This research used clustering random sampling to select sample in such a way that all individuals in the defined population had an equal and independent change of being selected sample. At beginning, researcher had chosen 600 students of Budhi Warman I Senior High School, East Jakarta. There are 200 students from grade 10, 200 students from grade 11, 200 students from grade 12 and his/her mother. From 600 mothers only 457 mothers who returned the questionnaires and 57 mothers not completely answer the questionnaires. So, the respondents of this research are 400 respondents.

\section{Data Analysis}

In order to achieve the purposes of this research and test the hypotheses, SPSS 15.0 is used to analyze the data. Researcher conducted the following data analysis:

Descriptive Statistic Analysis. Descriptive statistic analysis was used to understand the characteristic of each variable. Respondent's profile was illustrated using descriptive statistic techniques in term of frequency distribution. Then, the mean and standard deviation of both independent and dependent variables are shown.

Factor Analysis and Reliability. To purify the measurement scale and to identify their dimension, principal components factor analysis was applied to condense the collected data into certain factors. After factor analysis, we use item-to-total correction and internal consistency analysis (cronbach's alpha) to confirm the reliability of each research factor.

Factor analysis assumes that a small number of unobserved variables (i.e. latent) constructs are responsible for the correlation among a large number of observed variables. The combination between factor analysis and results and construct validity tests can maintain a good understanding of the quality of the study measurements (Hair et al. 2006).

To verify the dimension and reliability of the research construct and purification processes including factor analysis, correlation analysis and internal consistency analysis (cronbach's alpha) were conducted in this study. Factor analysis was first employed to identify the dimension of each research construct, to select questionnaire items with high factor loadings, and to compare these selected items with item suggested theoretically. Item-to-total correlation and coefficient alpha are assessed to identify the internal consistency and reliability of the construct. Latent roots (eigenvalues), screen test, and other criteria were used to determine the number of dimensions to be extracted from the principal component factor analysis. This research used principal component factor analysis and varimax rotated method to extract the relevant factors. The essential criteria in terms of the value of factor of each variable loading are greater than 0.6 (factor loading $\geq 0.6$ ), eigenvalue $\geq 1$. In reliability analysis, the item-to-total correlation must be greater than 0.5 (item-to-total correlation $\geq 0.5$ ) and at least not below 0.35 . Cronbach's coefficient alpha ( $\alpha)$ must be larger than $0.6(\alpha \geq 0.6)$ (Hair et al. 2006).

Parental Value. Factor analysis result showed high degree of internal consistency of the factors parental values factor. There were five factors identified to explain this dimension. From 20 items of parental belief and value, eight items has been deleted. The rest have the factor loading greater than 0.6. There is one factor to explain the construct of perfectionist (eigenvalue=5.297, $\alpha=0.846$ ) with the total variance explained of $65.23 \%$. Item to total correlation of the items are above 0.352. Based on all criterions, this study can conclude that the reliability and internal consistencies of this factor is acceptable.

Parenting Style. Factor analysis result showed that high degree of internal consistency of the parenting style factor. The eigenvalue extracted from the factor analysis of parenting style is 2.60 with the total variance explained of $60.93 \%$. The construct also yield high value of reliability $(\alpha=0.63)$. It is also shown that all variables within factor tend to have a high 
coefficient of item-to-total correlation $(\geq 0.35)$. Based on all criterions, this study can conclude that the reliability and internal consistency of this factor is acceptable.

Family-School Connection. Result showed high degree of internal consistency of family-school connection factor. The eigenvalue extracted from the factor analysis of family-school connection is 3.07 with the total variance explained of $43.91 \%$. The construct also yield high value of reliability $(\alpha=0.78)$. It is also shown that all variables within factor tend to have a high coefficient of item-tototal correlation $(\geq 0.46)$. Based on all criterions, this study can conclude that the reliability and internal consistency of this factor is acceptable.

Family-Community Connection. Result showed that high degree of internal consistency of family-community connection factor. The eigenvalue extracted from the factor analysis of family-community connection is 4.15 with the total variance explained of $53.18 \%$. The construct also yield high value of reliability $(\alpha=0.79)$. It is also shown that all variables within factor tend to have a high coefficient of item-to-total correlation $(\geq 0.35)$. Based on all criterions, this study can conclude that the reliability and internal consistency of family-community connection measurement is acceptable.

\section{One Way ANOVA Test}

The one way ANOVA test compares the means of more than two different samples. Comparison test used for analyze the differences research variables based on parental belief and values and parenting style.

\section{Inferential Test}

Correlation analysis is used to look for significant correlation between socioeconomic status, family-school connection, family-community connection, parental belief and value, and parenting style. Regression analysis was used to identify influencing factors of major variables.

\section{RESULT AND DISCUSSION}

\section{Parental Values}

One way ANOVA was used to determine whether parental values are significantly different in the term of father ethnic. Parental values subscale of continuity, tradition, and security; parental satisfaction, role motivation, social status, happiness, and affection were not significant differences in term of father ethnic. Only subscale of goal incentives from the children which different based on father ethnic $(F=2.87, p=0.015)$. Fathers who came from Batak and Java ethnic had higher mean score than father who came from the other ethnics. The total of parental value was not significantly different on father ethnic.

The second research question hypothesized that parental value was significantly different on mother ethnic. To analyze this prediction, one way ANOVA was conducted. Result showed there was significant differences on parental values subscale continuity, tradition and security in term of mother ethnic $(F=3.03 ; p=0.011)$. The rest of parental value subscales and total of parental values were not significantly different on mother ethnic.

One of the main purposes of this study was to verify the differences of parental value under differentiation of socioeconomic status level. There were significantly different between socioeconomic status $(F=4.802 ; p=0.009)$ in parental value subscale of happiness and affection. Family with medium level of socioeconomic status had higher mean score for parental value than family with high and low socioeconomic status.

\section{Parenting Styles}

In term of ethnic, there was significantly mean differences in permissive parenting style ( $\mathrm{F}=2.39$; $p=0.04)$. Fathers who came from Sundanese ethnic had greater mean score than fathers from the other ethnics. Authoritarian and authoritative parenting style were not significantly different on father ethnic.

This study also would like to determine whether parenting style significantly different in term of mother ethnic. One way ANOVA showed there were not significantly different on parenting style based on mother ethnic variable.

Results of the ANOVA showed that there were significantly mean different in authoritarian parenting style in the term of 
socioeconomic status $(F=5.273 ; p=0.005)$, family with socioeconomic level 2 had greater mean score than family from family from high level of socioeconomic status. In addition, there no significantly mean different in permissive parenting style and authoritative parenting style in term of socioeconomic status.

\section{Correlation between Variables}

Correlation analysis was conducted to test the hypothesis. Result showed that socioeconomic status variable had significantly negative correlation with parental value subscale of social status $(r=-0.118 ; p<0.05)$, subscale of happiness and affection $(r=-0.161 ; p<0.01)$ and authoritarian parenting style $(r=-0.156$; $p<0.01)$. There was no significantly positive correlation of socioeconomic status with the other variables.

Regarding of socioeconomic status, socioeconomic status had negative significant correlation with parental values subscales social status and happiness and affection; and also had negative correlation with authoritarian parenting style. It consistent with previous research over 45 years ago, Kohn (1963) proposed that parents from various social economic class levels differ in terms of what characteristics they value most for their children and that these differences in values contribute to differences in parenting behavior. Kohn (1977) and others (Wright and Wright 1976), using large, representative national samples, had repeatedly demonstrated that social class is related to parental values for both mothers and fathers.

The family-school connection $(r=0.125 ; \quad p=<0.01)$ were significantly positive correlated with total parental value, such that as family-school connection increases so does the reported of the parental value.

Traditionally, public schools have not had a strong emphasis on family involvement and support. Schools of education have typically offered little direct training in forming parent/teacher relationships. A 1987 University of Minnesota report on improving teacher education listed what researchers identified as the thirty-seven most important teaching skills; learning how to work with parents was not among them (Louv 1992). This study result showed that family-school connection significantly related and correlated with parental values and parenting style. Family-school connection also had significantly dependency with those variables. This result consistent with previous research by Napier and Whitaker (1978) which said that schools and families are interdependent institutions that rely on each other as sources of influence, models for development, and places and spaces of constructive interactions. It is important to develop a harmonious relationship between the two, in order to generate a school environment and cultural climate that positively influences children's interpersonal relationships, promotes a high degree of security, and develops critical thinking skills. In order to improve quality in education, it is essential that the school and families foster the transfer of values, competencies, and knowledge that will in turn educate children to become successful members of society.

The family-community connection $(r=0.25 ; \quad p<0.01) \quad$ were significantly positive correlated with total parental values, such that as family-community partnership are increase so does the reported of the parental value. Familycommunity connection variable had positive significant correlation with almost parental values subscales that were continuity, tradition, and security variable $(r=0.187 ; \quad p<0.01)$, parental satisfaction $(r=0.229 ; \quad p<0.01)$, role motivatition $(r=0.117 ; \quad p<0.05), \quad$ happiness and affection ( $r=0.260 ; p<0.01)$ and goal incentives from child $(r=0.253 ; p<0.01)$, except social status variable. Moreover, family-community connection had significant correlation with two parenting style that were authoritarian $\quad(r=0.10$; $p<0.05)$ and authoritative parenting style $(r=0.23 ; p \leq 0.01)$.

The needs and interests of family members change over the life span. Issues of responsiveness also change by aging and stage of development. "Community" refers to relationships and social networks as well as a physical location (Unger \& Sussman 1990). A family's informal social support networks often provide services that are more accessible, culturally appropriate, and acceptable than the services offered by formal support systems (Gottlieb 1988). 
Families are influenced by the cultural values and societal pressures in their communities (Farrow, Grant, \& Meltzer 1990).

This study result showed that familycommunity connection significantly correlated with parental values and significantly correlated with parenting style. This result consistent with previous research which said that theories of socialization place parenting in the context of the cultures and neighborhoods in which it occurs (e.g., McLoyd 1990; Sampson 1992; Super \& Harkness 1986). Several theoretically and empirically supported neighborhood characteristics that affect parenting include poverty, residential instability, public services, limited social networks, and danger (Furstenberg et al. 1993; Leventhal \& Brooks-Gunn 2000; Sampson; Wilson 1987, 1991a, 1991b as cited in Pinderhughes et al. 2001). In general, these neighborhood charac-teristics tend to undermine positive parental behaviors, such as warmth and appropriate and consistent discipline, and to increase problematic parental behaviors, such as harsh interactions (Furstenberg et al.; Klebanov, Brooks-Gunn, \& Duncan 1994 as cited in Pinderhughes et al. 2001). Although distinct neighborhood characteristics may exert unique effects on different parental behaviors (Leventhal \& Brooks-Gunn, and as cited in Pinderhughes et al. 2001), these specific relations have received little empirical study. Pinderhughes study examined the unique and combined effects of race, locality (urban vs rural community context), poverty, residential stability, public services, social networks, and danger on parental warmth, appropriate and consistent discipline, and harsh interactions, after controlling for the effects of family context and child behavior (Pinderhughes et al. 2001). These findings replicate quantitative findings that indicates positive neighbor aspect will support positive parenting. The degree to which family members trust others in their neighborhoods, their sense of community, and their concern for their safety are important factors in community involvement. In addition, participating in formal and informal social networks in a neighborhood provide families with more social connections, which, in turn, can support good parenting (Sampson 1992). Families can feel socially isolated in communities where such networks are nonexistent, which, in turn, can negatively affect parenting (Furstenberg et al. 1993; Pinderhughes et al. 2001).

\section{Mediator Variable}

The final research question predicted that parental value would mediate the relationship between independent variables (ethnic, SES, family-school connection, and family-community connection) and parenting style. Baron and Kenny theory was conducted to test this hypothesis.

\section{Testing Mediation}

Baron and Kenny (1986) proposed three conditions to be met in order for a variable as a mediator, that are 1) there is a significant relation between the independent variable and the mediator; 2) there is a significant relation between the mediator and the dependent variable; 3 ) when controlling for the relation between the independent variable and the mediator, a previously significant relation between the independent and dependent variables is decreased. Full mediation occurs when this relation is reduced to zero.

Because father ethnic, mother ethnic and socioeconomic status was not related to parental values, we could not test for mediation. Family-school connection and family-community connection were related to parental values. Thus, we investigated whether parental values mediate the relations of family-school connection and family-community connection with parenting style.

Baron and Kenny (1986) recommended that to test for mediation, one regress the dependent variable on the independent variable (Regression 1), regress the mediator on the independent variable (Regression 2), and then regress the dependent variable on both the independent variable and on the mediators (Regression 3). The key element that indicates a variable as mediator is the drop in the standardized regression coefficient for the independent variable (Regression 1) when the mediator is also included in the regression analysis (Regression 3). The Sobel test was used to further evaluate whether the 
change in the standardized regression coefficient for the independent variable from Regression 1 to Regression 3 (MacKinnon, Lockwood, Hofmann, West \& Sheets 2002). A significant Sobel test suggested that the level of mediation is meaningful.

Parental values as mediator between family-school connection and familycommunity connection and permissive parenting style.

First, we tested the potential role of parental value as mediator between family-school connection and permissive parenting style; also between familycommunity connection and permissive parenting style. When entered together in the regression analyses, family-school connection no longer predicted the permissive parenting style, but parental values significantly predicted permissive parenting style. Sobel test indicating that the change in the standardized regression coefficient is significant $(z=2.07 ; p=0.04)$. Thus, parental values partially mediate the association between family-school connection and permissive parenting style.

Family-community connection did not significantly predicted the permissive parenting style, but parental values significant predictor, indicating mediator. The Sobel test indicated that the change in the standardized regression coefficient for family-community connection is significant $(z=2.79 ; p=0.005)$. It suggested that parental values partially mediate the family-community connection and permissive parenting style.

\section{Parental values as mediator between family-school connection, family- community connection, and authoritarian parenting style. \\ When entering family-school} connection and parental values together in the regression analyses, family-school connection and parental value were predicted authoritarian parenting style. There was a drop in the standardized regression coefficient for family and school connection. The Sobel test indicated that the change in the standardized regression coefficient for family-school connection is significant $(z=2.271 ; p=0.023)$. It suggested that parental value partially mediates the relation between family-school connection, family community connection and authoritarian parenting style.

Family-community connection did not predict the authoritarian parenting style but parental values significantly predicted the authoritarian parenting style. The Sobel test indicated the change in the standardized regression coefficient is significant $\quad(z=3.523 ; \quad p=0.0004)$. It suggests parental values partially mediate between family-community connection and authoritarian parenting style.

Family-community connection did not predicted the authoritarian parenting style but parental values significantly predicted the authoritarian parenting style. The Sobel test indicated that the change in the standardized regression coefficient is significant $\quad(z=3.523 ; \quad p=0.0004)$. It suggests parental values partially mediate between family-community connection and authoritarian parenting style.

Parental value as mediator between family-school connection and familycommunity connection with authoritative parenting style.

This research evaluated whether parental values mediate the relation between family-school connection and authoritative parenting style, and mediate family-community connection and authoritative parenting style. When entered together in the regression analysis both family-school connection and parental values predicted the authoritative parenting style. The Sobel test, indicated that the drop in the standardized regression coefficient for family-school connection is significant, provided further evidence that parental values partially mediate the relationship between family-school connection and authoritative parenting style $\quad(z=2.00$; $p=0.045$ ).

Finally, it was evaluated whether parental values mediate the relation between family-community connection and authoritative parenting style. Both family-community connection and parental values predicted authoritative parenting style when entered together in the regression analysis. However, the Sobel test indicated the change of the standardized regression coefficient for family-community connection is marginally significant $(z=2.422 ; p=0.014)$. Based on multiple regression analysis 
result, the research construct will be like as figure 1 :

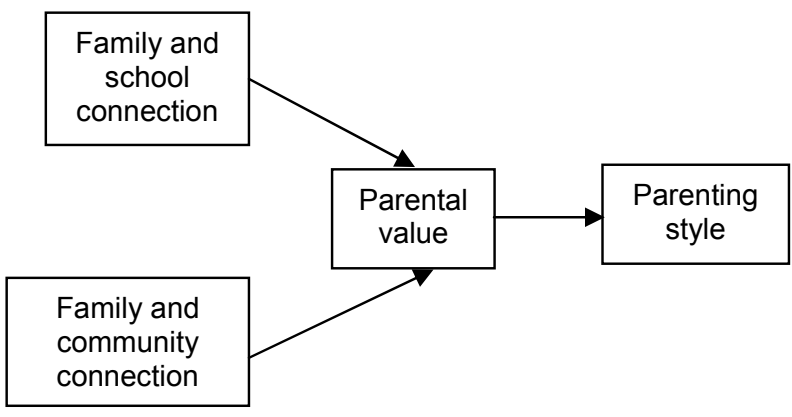

Figure 1. Research Construct

Although this research consistent with hypothesis that parental values are the partial mediator that mediates relations of family-school connection and family-community connection with parenting styles. But, parental values was not mediate relations of ethic, and socioeconomic variable with parenting styles. It recognized that there are other reasonable ways of conceptualizing the link between parental values and parenting style. This result consistent with previous research about parental values, it was said that one of three characteristics of parents that determine the process of parenting is parent values and goal (Darling \& Steinberg 1993). However, all things considered, the theoretical position that found was clearly explained that parental value is mediate relation of family-community connection with parenting style. It proved that Indonesian communities have strong relationship with their neighbor and in the relationship between neighbor is like a family. The member of communities often share and have together activity including share some families experience about parenting and parental value.

This study adds to the existing wealth of literature on parenting style from the family ecology aspect. Because the majority of previous research has been conducted with parenting style, it is still few research explore about parenting style from the family ecology perspectives. The results offer the opportunity to better understand the aspects that influence parental belief and values; and parenting style. And a deeper understanding of how some aspects can influence parental beliefs and vales about the children which can influence the pattern of parenting that parent applied. This study also utilizes family ecology theory, which allows for a process-oriented way of viewing how ethnics, socioeconomic status, familyschool connection, and family-community connection aspects mediated by parental belief and value affect parenting style.

\section{SUMMARY AND RECOMMENDATION}

\section{Summary}

The present study examined how ecological aspects (ethnic, socioeconomic status, family-school connection, and family-community connection) affected parenting style moderated by parental values. This study also sought to explore how parental values of the adolescent influenced the affect of parenting style in families with adolescent children. When all variables are included, the model predicted $3 \%$ of the variance for parenting style.

Parental values and parenting style seem significantly difference in some aspect based on parent ethnic and socioeconomic status. A goal incentive from children's value is difference in term of father ethnic, whereas continuity, tradition, and security value is different based on mother ethnic. Happiness and affection value is significantly difference on socioeconomic status. Permissive parenting style significantly difference in term of father ethnic and authoritarian parenting style significantly different in term of socioeconomic status

Family-school connection and familycommunity connection were shown to be most predictive of both parental values and parenting style. Ethnic, socioeconomic status, important in this study, but did not predicted as much of the variance as family-community connection and family-school connection. Parental values were proved to be important moderators when interacting with the family-school connection and familycommunity connection variables to predict parenting style. Parental values interacting with family-school connection and family-community connection were significant predictor of parenting style. This information is valuable for the teacher or family educator who working 
with adolescents and their families. By helping families work through difficult issues such as adolescent substance use, teens can continue to grow resilient and be well-adjusted.

\section{Recommendation}

Future research needed to corroborate the multiple perspectives and observations of families to further substantiate the impact of these factors on parenting style. Although, considerable data in the literature demonstrate that measurement of self-reported substance had good validity and reliability (Needle, McCubbin, Hamilton, Lorence, \& Hochhause, 1983), in order to better develop parenting style effect on the adolescent, it is essential to observe adolescent development outcome to identify the effect of parenting style on children

Further research is warrant to explore how ethnicity and socioeconomic status may be mediated by other variables to affect parenting style. Finally, this study highlights the need for conducting longitudinal research when investigating process and outcome of parenting in adolescent. Future studies might make use of designs that include more assessment points to take fuller advantage of the power of growth curve methodology since it is unlikely that the variations in the impact of parenting processes would be uncovered with cross-sectional designs.

\section{REFERENCES}

Abar B, Carter KL, Winsler A. 2009. The effects of maternal parenting style and religious commitment on self regulation, academic achievement, and risk behavior among AfricanAmerican paarochial college students. Journal of Adolescent 32:259-273.

Baron RM, Kenny DA. 1986. The moderator-mediator variable distinction in social psychological research: Conceptual, Strategic, and statistical considerations. Journal of Personality and Social Psychology, 51:1173-1182.

Brofenbrenner U. 1979. The Ecology of Human Development [electronic version]. Cambridge, MA. Harvard: University Press.

1992. Ecological

Systems Theory. In R. Vista (Ed). Six theories of child development: Revised formulations and current issues (pp. 187-249). London: Jessica Kingsley.

. 2000. Ecological Systems Theory. In A.E. Kazdin (Ed.), Encyclopedia of psychology, (Vol. 3, pp. 129-133). Washington, DC: American Psychological Association.

Buchanan CM, Holmbeck GN. 1998. Measuring belief about adolescent personality and behavior [electronic version]. Journal of Youth and Adolescence vol.27, No.5.

Buri JR. 1991. Parental authority questionnaire. Journal of Personality Assessment 57:110-119.

[CMS] Children Medical Service. 2004. Major Theories/Concepts of Human Growth and Development. http://www.doh.state.fl.us/alternatesit es/cms-

kids/ESproviders/ITDS/modules/mod ule01/lesson02/mod01_lesson2_3.ht $\mathrm{ml}$ [April, 29th 2008].

Darling N, Steinberg L. 1993. Parenting Style as Context: An Integrative Model. [Electronic Version] Psychological Bulletin vol 113, No. 3, 487-496. American Psychological Association, Inc.

Hair JJr, Black W, Babin BJ, Anderson RE, Tatham RL. 2006. Multivariate Data Analysis (6 eds). New Jersey: Prentice Hall.

Harkness S, Super CM. 2002. Culture and Parenting. In M. H. Bornstein (Ed.), Handbook of parenting. Volume 2: Biology and ecology of parenting (2nd edition), pp. 253-280. Mahwah, NJ: Erlbaum.

Harder AF. 2002. http://www.learningplaceonline.com/s tages/organize/family/stages.htm [June, 16th 2008].

Keats DM. 1997. Culture and The Children: A Guide For Professionals in Child Care and Development ( $\mathrm{pp}$ 43-44). England: John Wiley \& Sons Ltd.

Mancini JA, Bowen GL, Martin JA, Ware WB. 2003. The community conncetion index: measurement of sense of community and 
engagement. Hawaii International Conference on the Social Sciences, Honolulu.

Matas L, Arend R, Sroufe LA. 1978. Continuity of adaptation in the second year: The relationship between quality of attachment and later competence. Child Development 49: 547-556.

Miller NB, Cowan PA, Cowan CP, Hetherington EM. 1993. Externalizing in preschoolers and early

* Correspondence :

Email : sintasusanto_putri@yahoo.com adolescents: A cross-study replication of a family model. Developmental Psychology 29(1), 318. EJ 461700.

Paquette D, Ryan J. 2002. Brofenbrenner's Ecological System Theory.

http://www.doh.state.fl.us/alternatesit es/cms-

kids/ESproviders/ITDS/resource ban $\mathrm{k} /$ bronfenbrenners ecological.pdf [April, 29th 2008]. 